\title{
Additions to the myxobiota of Central America
}

\author{
Rojas $\mathbf{C}^{1,2}$ and Calvo $\mathbf{E}^{1}$ \\ ${ }^{1}$ Engineering Research Institute, University of Costa Rica, San Pedro de Montes de Oca 11501, Costa Rica. \\ ${ }^{2}$ Department of Agricultural and Biosystems Engineering, University of Costa Rica, San Pedro de Montes de Oca \\ 11501, Costa Rica
}

Rojas C, Calvo E 2014 - Additions to the myxobiota of Central America. Mycosphere 5(3), 488-495, Doi 10.5943/mycosphere/5/3/11

\begin{abstract}
Given the fact that until recently the myxomycetes were an understudied group in Central America, it is not surprising that the number of new records for most countries is currently increasing at a steady pace. This is significant in light of the fact that Central America is located within the Mesoamerican Biodiversity Hotspot and is projected to lose an appreciable percentage of its biodiversity due to global phenomena before the middle of this century. In the present study, which was conceived as an approach to equilibrate the information on myxomycetes among Central American countries, 23 unlisted records for Honduras, El Salvador and Costa Rica are provided. In particular, a record of the myxomycete Cornuvia serpula from the last country is noteworthy due its rarity in tropical areas of the world. The type of regional distributional information presented in this study represents baseline data for ecological monitoring purposes, which are essential for the conservation of the microbial biota and ecosystem functioning worldwide.
\end{abstract}

Key words - biogeography, Cornuvia serpula, distribution, myxogastrids, Neotropics

\section{Introduction}

The particular life cycle of myxomycetes (plasmodial slime molds or myxogastrids) has traditionally represented a challenge for those researchers trying to understand the macroecology of the group (Martin \& Alexopoulos 1969, Everhart \& Keller 2008). Most surveys carried out as part of studies of the diversity and biogeography of myxomycetes have been based almost exclusively on fruiting bodies. Ironically, these structures only represent the spore-producing stage of their life cycle (Schnittler \& Stephenson 2000, Everhart \& Keller 2008) and, as a result, most ecological information is incomplete. In spite of the latter, as an operational approach, most myxomycete researchers still collect fruiting bodies in order to build morphological libraries for future research.

Historically, studies on myxomycete diversity have been carried out primarily in temperate ecosystems of the northern hemisphere. Even though some researchers in the past have argued that both abundance and species richness are higher in temperate areas rather than in the tropics (Stephenson et al. 2004, Spiegel et al. 2004), such a pattern is still a matter of debate. In spite of the latter, a significant amount of recent studies in the Neotropical region have exposed an underestimated biodiversity (see Stephenson et al. 2004). Such studies have shown that approximately half of the known myxomycete species in the world occur in the Neotropics (Lado \& Wrigley de Basanta 2008). 
Within the Neotropical region, Central America is an interesting area for the occurrence of a number of species due its biophysical characteristics. The fact that the region is a natural land bridge between two large continental masses and is located between two oceans makes it unique. The large number of microenvironments provided by the range of macroecological and climatic conditions (see Lado \& Wrigley de Basanta 2008, Rojas et al. 2010a) is a key factor for the occurrence of a high diversity of plants and associated microflora. Since myxomycetes are associated with plant material, the probability for the group to find particular resources within this biodiversity hotspot is high (see Stephenson et al. 2008).

With the exception of Costa Rica, myxomycetes in Central America have been poorly studied. In the case of El Salvador, for example, the first records were published very recently (Rojas et al. 2013). For Honduras, the only important studies conducted to study the local myxobiota date back to the decade of the 1970s (see Farr 1976). Interestingly, the last report of a myxomycete from that country was not biogeographical in nature and actually described the presence of fruiting bodies of Physarum pusillum on the body of a living reptile (Townsend 2005).

Given the limited current knowledge of myxomycetes in the region, the primary objective of this study was to contribute to the generation of distributional information about the group in Central America. In particular, the idea for this project was to increase the number of species known within an understudied biodiversity hotspot as a way to increase the library of ecological information and baseline data on the dynamics of microorganisms in natural ecosystems. The potential implications of this type of studies are significant in the diverse, heterogeneous and endangered ecosystems of the area under study.

\section{Materials \& Methods}

The present study was carried out during 2013 in El Salvador, Honduras and Costa Rica. The morphological concept of species has been used and the nomenclatural treatment follows Lado (2005-2014). For abbreviations, country codes are provided according to the ISO 3166-1.

\section{Study areas}

Five study areas distributed across the Central American region were selected for this study (Figure 1). The first of these areas corresponds to the buffer zone of La Tigra National Park in Central Honduras (hereafter referred to as La Tigra). This area is located between 14.173642 14.175554 N and 87.133465 - 87.133064 W in the Francisco Morazán Department. The forest type in this area corresponds to a lower montane moist forest and the section surveyed was a Pinus dominated patch at around $1450 \mathrm{~m}$ of elevation.

The second area is the historical center of the Montecristo National Park (here after referred to as Montecristo). This area is located in the Department of Santa Ana in northern El Salvador within a premontane moist forest at $14.362295 \mathrm{~N}$ and $89.403353 \mathrm{~W}$. The forest surveyed is a riparian patch at $845 \mathrm{~m}$ elevation on the southern side of the San José Ingenio historical village. The third area, also within the Montecristo National Park in El Salvador is known as Mirador El Infiernillo (referred to as Infiernillo). This area is within a lower montane moist forest at 14.39356 $\mathrm{N}$ and $89.38577 \mathrm{~W}$ and located at elevation of $1615 \mathrm{~m}$. The forest is represented by a mixed Quercus-Alnus-Pinus assemblage on a steep slope of the mountain facing the canyon of the San José river.

The fourth area is the Miravalles Volcano (referred to as Miravalles) in northern Costa Rica at $10.712750 \mathrm{~N}$ and $85.154060 \mathrm{~W}$ and located at an elevation of approximately $1000 \mathrm{~m}$. This area is comprised of a premontane moist forest on the southern slope of the volcano around $4 \mathrm{~km}$ northeast of the town of Guayabo de Bagaces. Finally, the last area is the Las Tablas Protected Zone in southern Costa Rica (referred to as Las Tablas). This area is represented by a lower montane wet forest dominated by Quercus at around $1700 \mathrm{~m}$ elevation. Located at $8.923192 \mathrm{~N}$ and $82.79334 \mathrm{~W}$, this is the southernmost surveyed area and represents the buffer zone for the La Amistad International Park between Costa Rica and Panama. 


\section{Sampling and annotations}

The results presented in this paper are part of a rapid assessment project in Central America. As such, both field and laboratory protocols were used to record the species presented. During the field component of the research, the opportunistic method described by Cannon \& Sutton (2004) was used. Unfortunately, in some research areas, field collections could not be made due to permit restrictions. In such cases, species were identified in the field.

For the laboratory component of this investigation, the moist chamber culture method (abbreviated as MC) described by Stephenson \& Stempen (1994) was used. A total number of 418 cultures using ground litter as a substrate for isolation of myxomycetes were prepared from the same number of samples collected at different sites from all different areas. Following this protocol, samples were placed on Petri dishes previously lined with filter paper. Distilled water was added to saturate the samples and after a $24 \mathrm{~h}$ period, the excess water was poured off the plate, $\mathrm{pH}$ was measured and the cultures were observed for at least three months. When necessary, water was added in order to maintain a moist environment within the culture. When fruiting bodies were found, these were extracted with forceps and glued into a match box. All specimens curated in this manner have been deposited at the University of Costa Rica herbarium (USJ) for future reference.

The species list compiled contains a series of annotations. In all cases the species name is provided along with the respective protolog. After this, the names of collectors, number of collections and respective collecting number of the studied specimens are provided. A reference to the source of the collection (either field or moist chamber collection) or field observation and the year in which such record was made are also provided. Finally, the area where the material came from, the substrate and a reference to the $\mathrm{pH}$ values (when available) are presented.

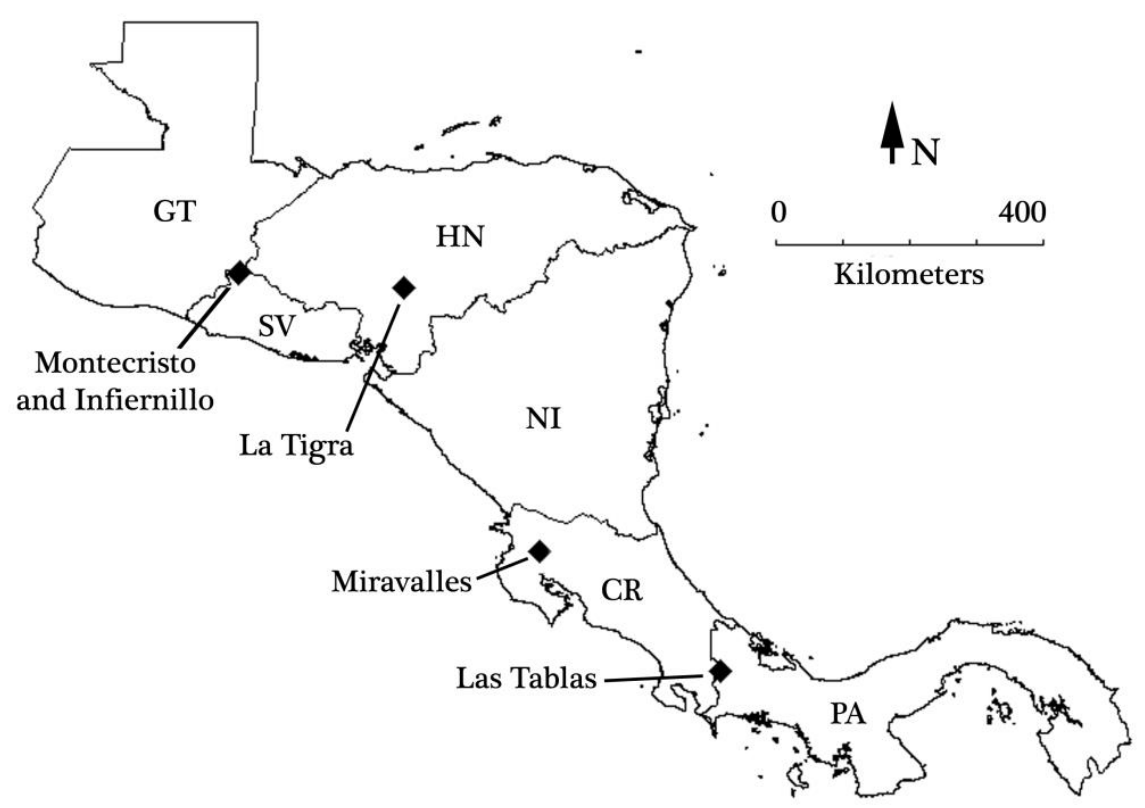

Figure 1 - Map of Central America showing the localities used in the present investigation. For full names and description of the areas see the Materials and Methods section. Abbreviations correspond to Guatemala (GT), Honduras (HN), El Salvador (SV), Nicaragua (NI), Costa Rica (CR) and Panama (PA).

\section{Results}

Overall, a total of 49 species of myxomycetes were recorded in this study. Out of the total, 23 species represented new reports for the respective countries. Approximately $40 \%$ of the moist chamber cultures yielded positive results (either fruiting bodies or plasmodia) for myxomycetes. 
The most common species recorded from the regional ground litter analysis were Perichaena pedata (25 records) and Arcyria cinerea (19 records). The percentage of positive moist chamber cultures varied among the countries. In Honduras and El Salvador the value reached approximately $65 \%$, whereas in Costa Rica it was only $24 \%$. Most of the new records for the respective countries had previously been reported from the Neotropical region, according to Lado \& Wrigley de Basanta (2008). However, Cornuvia serpula, a species recorded from Las Tablas in southern Costa Rica, represents a new record for this section of the Neotropics (Figure 2).

When analyzing only moist chambers, the structure of the myxomycete assemblages seemed to differ among the various study areas. In the Costa Rican sites, Cribraria violacea, Diderma effusum and Perichaena chrysosperma were the most commonly recorded taxa. However, these species were not recorded in the moist chamber cultures prepared with substrates from the other two countries. Similarly, in Honduras and El Salvador, species such as Perichaena pedata and Cribraria microcarpa were commonly recorded, but they were rare or absent from Costa Rica.

The annotated list of species provided below shows the new records of myxomycetes for the three countries studied during the present investigation which added 20, three and two new species for Honduras, El Salvador and Costa Rica, respectively. Such a result increases the number of known species from known all three countries to 32, 40 and 212 in the same order as used above.

\section{New records of myxomycetes from Central American countries}

For the annotated list, the abbreviations used are: MC (moist chamber collection), GL (ground litter) and DW (decaying wood).

Clastoderma debaryanum A. Blytt

C. Rojas and E. Calvo Ro-3620, 1 collection. From MC, 2013. La Tigra National Park, HN, on GL, $\mathrm{pH}=6.5$.

Comatrichia pulchella (C. Bab.) Rostaf.

C. Rojas and E. Calvo Ro-3637, 1 collection. From MC, 2013. La Tigra National Park, HN, on GL, $\mathrm{pH}=6.1$.

Cornuvia serpula (Wigand) Rostaf.

C. Rojas and E. Calvo Ro-3559, 1 collection. From MC, 2013. Las Tablas Protected Zone, CR, on $\mathrm{GL}, \mathrm{pH}=7.4$.

Cribraria microcarpa (Schrad.) Pers.

C. Rojas and E. Calvo Ro-3671, 3678, 2 collections. From MC, 2013. La Tigra National Park, HN, on GL, $\mathrm{pH}$ range $=6.2-6.7$.

Cribraria languescens Rex

C. Rojas, not collected. Field observation, August 2013. La Tigra National Park, HN, on GL, no pH data.

Cribraria violacea $\mathrm{Rex}$

C. Rojas and E. Calvo Ro-3609, 1 collection. From MC, 2013. La Tigra National Park, HN, on GL, $\mathrm{pH}=7.6$

Diachea leucopodia (Bull.) Rostaf.

C. Rojas, not collected. From MC, 2013. La Tigra National Park, HN, on GL, pH = 6.0.

Diderma effusum (Schwein.) Morgan

C. Rojas and E. Calvo Ro-3670, 1 collection. From MC, 2013. La Tigra National Park, HN, on GL, $\mathrm{pH}=5.9$.

Diderma hemisphericum (Bull.) Hornem.

C. Rojas, not collected. From MC, 2013. La Tigra National Park, HN, on GL, pH =6.8.

C. Rojas, not collected. From MC, 2013, Montecristo National Park, SV, on GL, pH = 7.7.

Diderma spumarioides (Fr.) Fr.

C. Rojas Ro-3592, 3593, 2 collections. From MC, 2013. Miravalles Volcano, CR, on GL, pH = 7.5. 


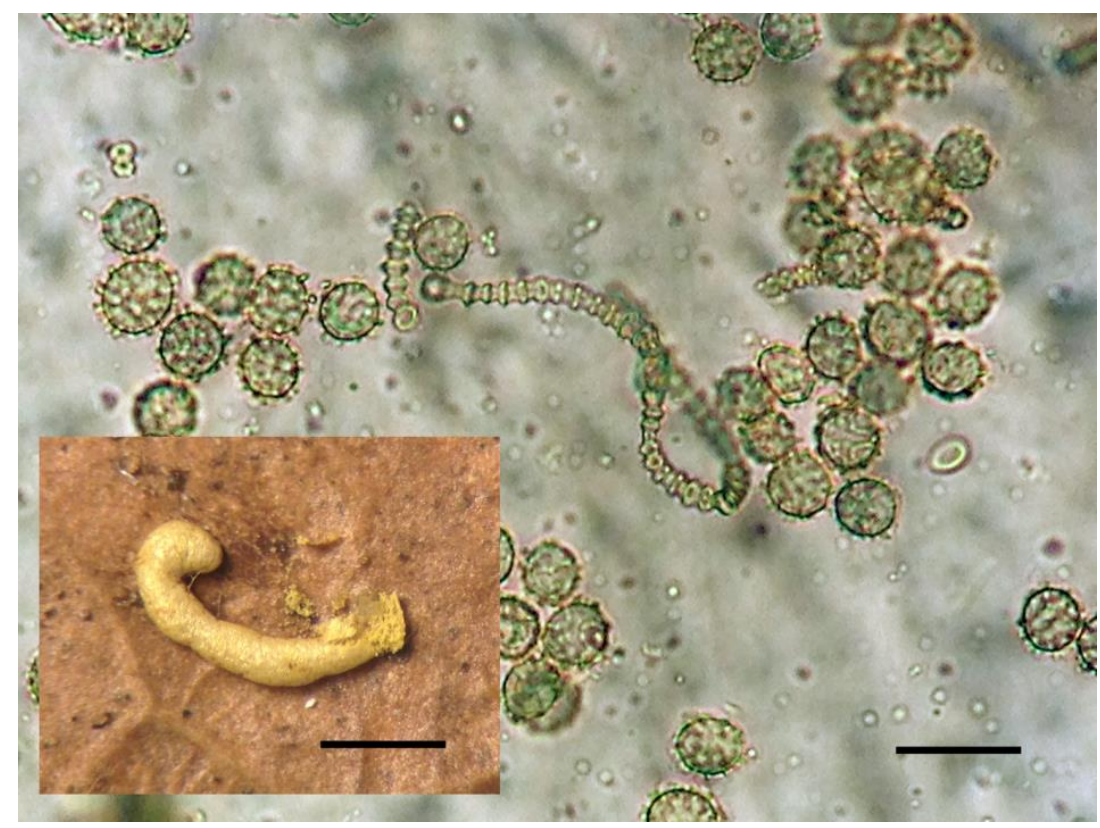

Figure 2 - Microphotograph of the reticulate spores and ringed capillitium of the collection Ro3559 corresponding to the myxomycete Cornuvia serpula from Las Tablas in southern Costa Rica. The insert corresponds to the macroscopic morphology of the fruiting body.Scale bars $=20 \mu \mathrm{m}$ (microscopic) and $1 \mathrm{~mm}$ (insert).

Didymium nigripes (Link) Fr.

C. Rojas and E. Calvo Ro-3695, 1 collection. From MC, 2013. Montecristo National Park, HN, on $\mathrm{GL}, \mathrm{pH}=7.6$.

Didymium squamulosum (Alb. \& Schwein.) Fr. \& Palmquist

C. Rojas and E. Calvo Ro-3611, 3623, 3633, 3 collections. From MC, 2013. La Tigra National Park, HN, on GL, $\mathrm{pH}$ range $=6.8-7.6$.

Hemitrichia pardina (Minakata) Ing

C. Rojas and E. Calvo Ro-3629, 1 collection. From MC, 2013. La Tigra National Park, HN, on GL, $\mathrm{pH}=6.5$.

Lycogala epidendrum (L.) Fr.

C. Rojas, not collected. Field observation, August 2013. La Tigra National Park, HN, on GL, no pH data.

Perichaena chrysosperma (Curr.) Lister

C. Rojas and E. Calvo Ro-3608, 1 collection. From MC, 2013. La Tigra National Park, HN, on GL, $\mathrm{pH}=7.1$.

Perichaena pedata (Lister \& G. Lister) Lister ex E. Jahn

C. Rojas and E. Calvo Ro-3615, 3616, 3617, 3618, 3624, 3626, 3627, 3628, 3638, 3639, 3673, 3674, 12 collections. From MC, 2013. La Tigra National Park, HN, on GL, pH range = 5.9-7.2.

Physarum bogoriense Racib.

C. Rojas and E. Calvo Ro-3676, 3677, 2 collections. From MC, 2013. La Tigra National Park, HN, on $\mathrm{GL}, \mathrm{pH}=6.0$.

Physarum cinereum (Batsch) Pers.

C. Rojas and E. Calvo Ro-3621, 1 collection. From MC, 2013. La Tigra National Park, HN, on GL, $\mathrm{pH}=7.0$.

Physarum melleum Berk. \& Broome) Massee

C. Rojas and E. Calvo Ro-3635. 1 collection. From MC, 2013. La Tigra National Park, HN, on GL, $\mathrm{pH}=6.9$. 
Physarum stellatum (Massee) G.W. Martin

C. Rojas, not collected. Field observation, July 2013. Montecristo National Park (Infiernillo), SV, on DW, no $\mathrm{pH}$ data.

Physarum tenerum Rex

Rojas and E. Calvo Ro-3614, 1 collection. From MC, 2013. La Tigra National Park, HN, on GL, $\mathrm{pH}=6.4$.

Stemonitopsis aequalis (Peck) Y. Yamam.

C. Rojas and E. Calvo Ro-3636, 1 collection. From MC, 2013. La Tigra National Park, HN, on GL, $\mathrm{pH}=6.4$.

\section{Discussion}

It is not surprising to list more than 20 new records for different countries in Central America resulting from a rapid assessment project. The low number of undocumented species recorded during this investigation for Costa Rica corresponds to the expectation for that country (see Rojas et al. 2010b). Similarly, the number of new myxomycetes recorded from Honduras is understandable, considering that this group of organisms has not been studied in decades. The few new records for El Salvador, all in the Montecristo National Park area, simply seem to correspond to species that were missed during the recent surveys made in the park (see Rojas et al. 2013).

Most of the recorded myxomycetes from all areas are among the common species to be expected from equivalent areas in the tropics. For example, the genera Cribraria, Diderma and Perichaena have been systematically recorded in mountainous tropical areas (e.g. Ko Ko et al. 2010). However, the record of Cornuvia serpula from the present study is a rare finding for the Neotropics, and it is also currently being communicated from Mexico (Estrada-Torres A, personal communication). However, our record was collected at ten degrees of latitude and thus, extends the geographical range known to the species in this part of the world. Interestingly, $C$. serpula has been found within a highly unexplored Quercus-dominated area that should probably be further studied for myxomycetes.

In spite of such a rare finding, other species such as Diderma effusum and Perichaena chrysosperma are among the most common myxomycetes fruiting in moist chambers when tropical ground litter is used as a substrate. In this way, these species support previous patterns observed in other studies. It is interesting, however, that both species produce either plasmodiocarps or sessile sporangia (see Martin and Alexopoulos 1969), suggesting that such fruiting body types may be favored when moist chambers prepared with ground litter are studied. An analysis of the reasons why these species were so common in Costa Rica but not in El Salvador or Honduras requires a higher sampling effort and a comprehensive ecological assessment. Interestingly, results seem to show that the level of ecological heterogeneity in the region may be partially responsible for such patterns.

One interesting aspect recorded in the present study was the low rate of positive moist chambers made with substrates from the study areas. In this investigation only about $40 \%$ of the cultures yielded positive results for myxomycetes. Similar surveys in temperate areas are known to result in much higher positive rates (sometimes higher than 90\%, see Goad \& Stephenson 2013) and even other studies from tropical areas have recorded higher values (e.g. Rojas and Stephenson 2008). However, higher elevations in Central America do not seem to correspond to areas with highly productive substrates, as has been observed in previous studies as well (Rojas and Stephenson 2007). The latter observation seems to be supported by results from the present study.

In summary, our study represents one more effort to contribute to the knowledge of myxomycete distribution in the Central American region. As is the case for other biodiversity hotspots in the world, this region is still underexplored in a biological sense. However, the opportunity of surveying this area for microscopic organisms such as myxomycetes is also accompanied by the responsibility of documenting the diversity of endangered forests. In this way, investigations like the one presented herein can serve as baseline studies for future programs on 
monitoring tropical forests under the frame of global phenomena such as climate change and human-induced activities such as forest fragmentation.

\section{Acknowledgements}

This project was funded by Vicerrectoría de Investigación from the University of Costa Rica through research code 731-B2-224. Gratitude is extended to Carolina Alduvín and Gustavo Cruz at the National Autonomous University of Honduras and to Ricardo Enrique Morales at the University of El Salvador in Santa Ana for logistical support. Appreciation is also extended to Martin Schnittler and Yura Novozhilov for checking the identification of some collections made during this project. Finally, gratitude is expressed to Steven L. Stephenson for important remarks in the final version of this manuscript.

\section{References}

Cannon P, Sutton B. 2004 - Microfungi on wood and plant debris; p. 217-239. In Mueller G, Bills G, Foster M (eds.). Biodiversity of Fungi: Inventory and Monitoring Methods. Elsevier Academic Press, Burlington, Massachusetts.

Everhart S, Keller H. 2008 - Life history strategies of corticolous myxomycetes: the life cycle, plasmodial types, fruiting bodies, and taxonomic orders. Fungal Diversity 29, 1-16.

Farr M 1976 - Flora Neotropica Monograph No. 16. (Myxomycetes). The New York Botanical Garden, New York.

Goad AE, Stephenson SL. 2013 - Myxomycetes appearing in moist chamber cultures on four different types of dead leaves. Mycosphere 4, 707-712.

Ko Ko TW, Hanh TTM, Stephenson SL, Mitchell DW, Rojas C, Hyde KD, Lumyong S, Bahkali AH. 2010 - Myxomycetes of Thailand. Sydowia 62, 243-260.

Lado C 2005-2014 - An on line nomenclatural information system of Eumycetozoa. Real Jardín Botánico de Madrid, Spain. http://www.nomen.eumycetozoa.com (accessed 21 April 2014).

Lado C, Wrigley de Basanta D. 2008 - A Review of Neotropical Myxomycetes (1828-2008). Anales del Jardin Botanico de Madrid 65, 211-254.

Martin GW, Alexopoulos CJ. 1969 - The Myxomycetes. University of Iowa Press, Iowa City, Iowa. USA.

Rojas C, Stephenson SL. 2007 - Distribution and ecology of myxomycetes in the high-elevation oak forests of Cerro Bellavista, Costa Rica. Mycologia 99, 534-543.

Rojas C, Stephenson SL. 2008 - Myxomycete ecology along an elevational gradient on Cocos Island, Costa Rica. Fungal Diversity 29, 117-127.

Rojas C, Stephenson SL, Estrada-Torres A, Valverde R, Morales O. 2010a - New records of myxomycetes from high-elevation areas of Mexico and Guatemala. Mycosphere, 1: 73-82.

Rojas C, Schnittler M, Stephenson SL. 2010b - A review of the Costa Rican myxomycetes (Amebozoa). Brenesia 73-74, 39-57.

Rojas C, Morales R, Calderón I, Clerc P. 2013 - First records of myxomycetes from El Salvador. Mycosphere 4, 1042-1051.

Schnittler M, Stephenson SL. 2000 - Myxomycete diversity in four different types of forest types in Costa Rica. Mycologia 92, 626-637.

Spiegel FW, Stephenson SL, Keller HK, Moore DL, Cavender JC. 2004 - Sampling the biodiversity of Mycetozoans. In Mueller GM, Bills G, Foster MS. (eds) Biodiversity of Fungi: inventory and Monitoring Methods. Elsevier Academic Press, Burlington, Massachusetts. Stephenson SL, Schnittler M, Lado C, Estrada-Torres A, Wrigley de Basanta D, Landolt JC,

Stephenson SL, Novozhilov YK, Clark J, Moore DL, Spiegel FW. 2004 - Studies of neotropical mycetozoans. Systematics and Geography of Plants 74, 87-108.

Stephenson SL, Schnittler M Novozhilov YK. 2008. Myxomycete diversity and distribution from the fossil record to the present. Biodiversity and conservation 17, 285-301. 
Stephenson SL, Stempen H.1994 - Myxomycetes: a Handbook of Slime Molds. Timber Press, Oregon.

Townsend JH 2005 - First report of sporangia of a myxomycete (Physarum pusillum) on the body of a living animal, the lizard Corytophanes cristatus. Mycologia 97, 346-348. 